\title{
QUEEN'S
UNIVERSITY
BELFAST
}

\section{Classifying labour regimes beyond the Welfare State: A two dimensional approach}

Ciccia, R. (2015). Classifying labour regimes beyond the Welfare State: A two dimensional approach. In S. O'Riain, F. Behling, R. Ciccia, \& E. Flaherty (Eds.), The Changing Worlds and Workplaces of Capitalism Palgrave Macmillan. http://www.palgrave.com/page/detail/the-changing-worlds-and-workplaces-of-capitalismseán-ó-riain/?sf1=barcode\&st1=9781137427076

Published in:

The Changing Worlds and Workplaces of Capitalism

Document Version:

Peer reviewed version

Queen's University Belfast - Research Portal:

Link to publication record in Queen's University Belfast Research Portal

Publisher rights

Seán Ó Riain (Editor), Felix Behling (Editor), Rossella Ciccia (Editor), The Changing Worlds and Workplaces of Capitalism (International Political Economy Series), Individual chapters Copyright Respective Authors 2015, reproduced with permission of Palgrave Macmillan' This extract is taken from the author's original manuscript and has not been edited. The definitive, published, version of record is available here: http://www.palgrave.com/gb/book/9781137427076.

\section{General rights}

Copyright for the publications made accessible via the Queen's University Belfast Research Portal is retained by the author(s) and / or other copyright owners and it is a condition of accessing these publications that users recognise and abide by the legal requirements associated with these rights.

Take down policy

The Research Portal is Queen's institutional repository that provides access to Queen's research output. Every effort has been made to ensure that content in the Research Portal does not infringe any person's rights, or applicable UK laws. If you discover content in the Research Portal that you believe breaches copyright or violates any law, please contact openaccess@qub.ac.uk. 


\title{
Classifying labour regimes beyond the Welfare State: $A$ two dimensional approach
}

\author{
Rossella Ciccia
}

Book chapter-forthcoming in O'Riain S., Behling F., Ciccia R., Flaherty E.(2015) The Changing Worlds and Workplaces of Capitalism, , Basingstoke: Palgrave MacMillan

\begin{abstract}
The tendency of previous research to subsume labour markets entirely within the domain of the welfare state has obscured differences in the extent and ways in which the commodification of labour has occurred across countries. This chapter aims to fill the gap in comparative research by making a distinct contribution to the development and operationalization of labour regime analysis. First, it advances the conceptualization of labour regimes as the intersection of two dimensions - selectivity and forms of regulation of employment relations -focusing on the ways in which labour is mobilized in different political economies. Second, it demonstrates the clustering of western European economies in four distinct regime types, which only partly overlap with prevailing welfare typologies. These findings are then used to advance debates about what kind of empirical and theoretical relationship exists between welfare and labour regimes.
\end{abstract}




\section{Introduction}

The labour market has been a favoured object of social science research. This is unsurprising considering that it represents both the main mechanism to allocate labour power to productive tasks and the primary source of social inequalities and class formation. However, the current transformations of work and the increasing diffusion of conditions that lie between the categories of employment and unemployment confront both advanced economies and mainstream theories of the labour market with new challenges. Moreover, in spite of the large number of scholarly works that have developed around the classification of advanced economies on several institutional domains, few works have analyzed the institutional variety of labour markets per se (Bosch, Lehndorff, and Rubery 2009; Gallie 2007a; Mingione 1997a; Rubery and Grimshaw 2003; Schmid and Gazier 2002).

The relative lack of comparative investigation on labour regimes appears largely related to the success of the 'welfare modelling business' (Abrahamson 1999) and in particular to the influence of Esping-Andersen's seminal work The Three Worlds of Welfare Capitalism (1990). Indeed, comparative labour market analyses appear flawed by persistent reference to this book, often starting with the assumption that certain forms of welfare directly cause distinct employment structures. Much of the attention dedicated to this book has focused on the idea of decommodification as the salient characteristic of different welfare regimes. Decommodification is defined as the extent to which individuals can maintain a livelihood independently from the market, and is measured through composite indicators based on replacement ratios and eligibility conditions for unemployment, pensions, and other income maintenance programmes. Therefore, commodification - the making of modern labour markets - and decommodification - the degree to which state policies render individuals free from the labour market- are generally treated as if they were symmetrical concepts: the more of one, the less of the other.

The general attention to those policies that protect people from labour market risks has concealed differences in the ways in which the commodification of labour has historically taken place across countries. In no modern society has all the population participated equally in productive tasks. In 2007, people in employment accounted for little more than $65 \%$ of the working-age population in Europe, in spite of a general upward trend in labour market participation ${ }^{1}$. The uneven inclusion of population groups in the labour market derives from the institutionalization of modern labour markets in the $19-20^{\text {th }}$ centuries, which proceeded together with the expulsion of certain activities from the 'legitimate' productive sphere. Housework and care work (Knijn and Ostner 2002) represent a great deal of those activities, but there are others that are normally neglected (e.g. education), while others have gained salience over time (e.g. 
retirement) (Lynch 2006). Through these activities, or rather 'inactivities', corresponding groups of the population were 'granted' the possibility to remain outside of the labour market, thus becoming optional or marginal labour force groups (Offe 1985). This suggests that variations in labour regimes relate not only to factors shaping how much work is available but also to factors influencing who considers themselves in the labour market or not (Rubery and Grimshaw 2003). A further source of variation in the commodification of labour concerns the differential diffusion of forms of standard and non-standard work. The standard employment relation was central to the Fordist regulation of labour in the golden-age of the postwar boom (Supiot 2001). Nevertheless, its predominance was a geographically limited and short-lived phenomenon. Forms of non-standard and informal work have always represented large amounts of labour in some national employment systems (Pfau-Effinger et al. 2009), while new forms of atypical employment have spread to different extents and in different ways across countries (Bosch et al. 2009).

Most scholars acknowledge that welfare states interact profoundly with the organization of labour markets; yet, the tendency of previous research to subsume labour regimes entirely within the domain of the welfare state has obscured differences in the extent, and ways in which, the commodification of labour has occurred across countries. This chapter aims to fill the gap in comparative research by making a distinct contribution to the development and operationalization of labour regime analysis. First, it advances the conceptualization of labour regimes as the intersection of two dimensions - selectivity and forms of regulation of employment relations -focusing on the ways in which labour is mobilized in different political economies, that is, the extent and ways in which various labour force groups (women, youth and older workers) are tied to the labour market over and above welfare state and other supports. Second, it demonstrates the clustering of western European economies in four distinct regime types, which only partly overlap with prevailing welfare typologies. These findings are then used to advance debates about what kind of empirical and theoretical relationship exists between welfare and labour regimes.

\section{Towards a typology of labour regimes: decommodification or commodification?}

A great deal of comparative research has investigated the institutional determinants of cross-country employment and unemployment differentials. These analyses typically focus on the role of a limited number of labour market institutions: collective bargaining, employment protection legislation, minimum wage and unemployment benefits (Amable et al. 2011; Baccaro and Rei 2007; Bassanini and Duval 2006; Belot and Van Ours 2004; Calmfors and Driffill 1988; Layard et al. 1991). A growing number of studies also investigate the effect of these same 
institutions on the employment of particular demographic groups, and especially of youth (Baranowska and Gebel 2010; Bertola, Blau, and Kahn 2007; Kahn 2007). Although they often adopt a cross-national research design, these analyses do not so much focus on countries but on the relationships, all else been equal, between certain factors and employment outcomes. Therefore, these investigations appear better equipped to appreciate similarities and convergence between national economies rather than differences.

The systematic comparison of national contexts represents instead the focus of a rather voluminous and interdisciplinary body of literature sometimes defined 'comparative capitalism research' (Deeg and Jackson 2007). This strand of research has produced a number of typologies of advanced economies according to their differences in certain institutional domains such as social protection, gender arrangements, industrial relations, corporate governance, financial systems, and skill formation. In particular, a bourgeoning amount of work has been dedicated to the idea that welfare systems come in different varieties that can be ordered according to idealtypical models (Bonoli 1997; Castles and Mitchell 1993; Esping-Andersen 1990, 1999; Ferrera 1993; Hicks and Kenworthy 2003; Huber and Stephens 2001; Jensen 2008; Korpi and Palme 1998; Lewis 1992; O’Connor et al. 1999; Sainsbury 1994; Titmuss 1958). Labour market institutions are usually considered within this strand of research only as one element of a broader set of dimensions used to explain differences in other institutional spheres (e.g. corporate governance) or as outcomes of different institutional structures (e.g. welfare states).

Much research has implicitly/explicitly assumed that a "welfare-state regime goes hand in hand with a peculiar labour-market regime", and even that "the labour market is systematically and directly shaped by the (welfare) state" (Esping-Andersen, 1990: 142, 144). Analyses of employment systems appear flawed by persistent reference to Esping-Andersen's renowned classification, often starting with the assumption that employment patterns will, by association or direct causation, fit his welfare typology. Therefore, the three worlds are commonly used in comparative labour market analyses as rationale for case selection, or worse still, interchangeably as synonymous with different employment regimes (Barbieri 2009; Erhel and Zajdela 2004; Gallie 2007b; Muffels et al. 2002). Nevertheless, the argument that welfare states and labour market characteristics cluster is rarely investigated through statistical techniques, and while they may often dovetail, there are important examples where they do not (Stephens 1994; Wincott 2001).

Esping-Andersen's work has provoked extensive debate; yet, his typology has proved robust and heuristically useful to understand empirical variation in social policy analyses. More problematic is its application to fields such as that of the labour market for which it was not initially developed. In this view, to describe the defining character of Scandinavian states as a high 
degree of decommodification of labour neglects other important features of these countries; namely, that they are characteristically biased towards full employment and leave few options for people to opt out of the labour market (Huo et al. 2008). Similarly, we cannot describe Southern European states as poorly decommodifying without taking notice of the low participation of their populations in salaried employment. As pointed out by feminist scholars (Lewis 1992; O'Connor et al. 1999; Orloff 1993; Sainsbury 1994), the essential flaw of decommodification is that individuals enter the analysis only once they have entered paid employment, while the ways in which (male) commodification relies on a whole set of other social and reproductive activities are left completely unexplored. The merit of feminist studies is to have brought both commodification and the household back into the theoretical debate. Nonetheless, the welfare state and its differential consequences for men and women remain steadily at the centre of their analysis.

\section{Defining labour regimes: selectivity and forms of regulations}

A starting point for the analysis of labour regimes comes from the work of Mingione, who defines a labour regime as "the set of relatively coherent and lasting rules of social life that consent to mobilize labour energies in typical forms" (1997:158). The word 'typical' is here used to refer to what is considered the 'normal', i.e. socially acceptable and widely spread form of organization of labour in a society. Others have used similar concepts in spite of using different labels: activity and employment regime (Barbier 1998) or employment systems (Bosch et al. 2009; Rubery and Grimshaw 2003; Schmid and Gazier 2002). All these definitions draw attention to the influence of legal, cultural and social norms on the ways in which employment and activity are distributed among the potentially active population (Barbier, 1998). Examples of these rules concern the definition of: 1) some activities as 'work' and others as 'non-work' (e.g. housework); 2) certain groups of people as compulsory labour force (e.g. prime-age men) and others as 'legitimately' inactive (women, youth, older people); 3) the conditions under which individuals enter/exit the labour force (e.g. retirement age, prohibition of child labour); 4) the ways in which labour power is delivered and disciplined within the employment relation. Accordingly, and based on these works, a labour regime is here conceptualized as the intersection of two dimensions: 1) the selection within the population of those who are destined/demanded to enter the labour force (who works?); 2) the different ways in which labour power is regulated within the employment relation, and in particular its distance/proximity from standard full-time employment typical of Fordist regulation of labour (how do they work?). It is worth noticing in comparison with Esping-Andersen's work, this definition looks at the end-product of 
commodification processes, i.e. the degree and the ways in which certain groups of individuals are tied to the labour market over and above welfare state and family supports. The next sections illustrate the historical relevance of these two dimension for the configuration of European labour regimes.

\section{The selection of the labour force: the creation of 'optional' labour force groups}

The selection of labour force groups has proceeded historically along a twofold path: the expulsion of some activities, and the exclusion of the corresponding groups of people from formal (at least primary) labour markets. The definition of 'work' and the resulting notion of employment are in fact historical products that identify certain social groups as 'employables' and others as 'unemployables' (Baxandall 2002). The state has normally played an important role in defining these boundaries around work and employment either through legal regulations that hinder some portion of the population from entering the labour market (e.g. the prohibition of child labour) or through the provision of non-market means of subsistence (e.g. old-age insurance, unemployment benefits) that influence the possibility of survival independently from salaried work (Offe 1985). A strategy common to all advanced economies in the post-war period has consisted in the quantitative restriction of labour supply through the extension of compulsory education and retirement schemes, which allowed respectively for the delayed entry of the new generations and the anticipated exit of the older ones into/from the labour market (Rubery and Grimshaw 2003). Similarly, the emergence of full-time housewifery as a mass phenomenon in the post-war period kept a great deal of women outside formal employment (Saraceno 1987). This suggests that national configurations of labour regimes are shaped in interaction and facilitated by a whole set of institutions that reproduce labour itself, and particularly, the family, the educational and training system and social security system (Bosch et al. 2009). Therefore, while we need to separate these different spheres conceptually, it is possible that there are linkages and interdependencies between them. This becomes clear when we consider the ideal typical post-war labour regime based on the combination of men's life-long full-time employment, with care provided by full-time housewives and generous welfare state supports (Lewis 1992). This settlement has been variously defined 'Fordism', 'male bread-winner' model or 'welfare capitalism' depending on the relative emphasis given to its three elements.

A labour regime is thus relatively stable over relatively long periods of time and made visible according to standard categories such as gender and age ${ }^{2}$. However, the license to a life outside the labour market appears as a highly ambivalent Greek gift, since those criteria which are used to define 'optional' labour force groups (i.e. gender and age) are the same characteristics that identify problem groups inside the labour market (Offe, 1985). Indeed, employment differentials across European economies are essentially related to the differential labour market engagement of women, youth and older people (OECD 2006). Nevertheless, public policies may also aim at the inclusion of larger portions of the population in waged work as shown by states' increasing 
emphasis on activation, individual obligations and work incentives (Gilbert, 2002). Among inclusion strategies, we also find negative actions aimed at increasing dependence on earned wages, such as the reduction of the length and amount of unemployment benefits or the mitigation of the protective function of labour law (Bonoli, 2003). These processes and policies are played out differently across European economies, particularly with regard to the specific groups targeted by such measures (e.g. lone parents, mothers of young children, people with disability, older unemployed) (Clasen and Clegg 2011), which contributes to persisting crossnational differences in the incorporation of particular demographic groups in paid employment.

\section{Regulating labour: from Fordist regulation of work to non-standard employment relations}

The second dimensions is concerned with the regulation of the employment relation, and the differential diffusion of forms of standard and non-standard work. Differences in the ways in which labour is regulated across advanced economies are generally considered as part of the development of divergent forms of capitalism (Bosch et al. 2009; Rubery and Grimshaw 2003). According to Mingione (1997: 95-146), we can distinguish the following regulation phases: extensive (from the industrial take-off to the First World War); intensive (from the end of WWI to the oil crises of the 70s), and the current phase of fragmented or flexible regulation. The transition from one phase to the next was characterized by different prevailing socio-economic forms and dynamics of changes. It is also important to stress that each phase far from being uniform, has instead occurred in partially diverse ways across societies according to pre-existent institutions and historical legacies.

The first extensive phase was aimed at horizontal extension of the capitalist way of life through the substitution of old traditional institutions (rural economies, auto-consumption, crafts) with others consistent with the development of industrial wage-earning societies. The diffusion of monetary consumption and waged labour were made possible in this period by the increase in proletarianization - for which people come to depend increasingly on a salary for their living- and commodification - the growth in the number of goods and activities produced for exchange via the market. A well-known historical example of these processes are the English enclosures and the dismantlement of the Speenhamland system in the nineteenth century (Polanyi 1944). The social and economic sustainability of this model was compromised at the end of the nineteenth century by the increasing pauperization of the population and the periodic recurrence of over-production crises (Arrighi et al. 1999).

The main issue of the second period (Fordism) was no longer the production of cheap labour, but rather the creation of forms of regulation to make compatible the demand for a highly productive workforce with the expansion of mass markets for the goods produced by large corporations centred on the exploitation of economies of scale (Boyer 1986). This production system was based on high wages and welfare, secured at least in Europe through extensive state intervention (Keynesism). This model was not only a form of organization of production, but rather a broader form of social organization deeply reshaping the lives of individuals and 
households, from which stems its intensive character (Gramsci 1949). It is in this period that the standard employment relation becomes the prevalent form of regulation of labour exchanges. Labour regimes are based in this period on the permanent, socially protected, full-time, dependent employment of adult males earning a primary/family income (Bosch 2004). The implementation of the Fordist production and employment regimes in many countries and industries has been partial at most. For instance, the persistence of crafts and professional markets in Germany and Sweden considerably limited the adoption of Fordist and Tayloristic principles of work organization, while southern European economies were based on widespread use of cheap labour, protectionism, and state intervention to support the delayed industrialization (Koch 2004). Nevertheless, the Fordist model will dictate the interpretative categories of this era .

The causes of the crisis of the intensive/Fordist regime are generally identified as a range of phenomena profoundly reshaping advanced economies: 1) demographic dynamics reducing the share of people actively participating in labour markets (Vos 2009); 2) the saturation of mass consumer markets and the growing importance of service and financial activities (Iversen and Wren 1998); 3) the widespread entry of women into paid employment and the unravelling of the Fordist gender contract (Crompton 2006); and 4) increased economic competition and the integration of markets on a global scale (Spilerman 2009). The interpretation of the third phase remains unclear inasmuch that it is often defined only by contrast with the others and referring to such different phenomena as neoliberism, globalization and post-Fordism. (Littlewood et al. 2004). A term commonly used to describe it is flexibilization, although it is used in so many different and contradictory ways that almost any study unavoidably starts by declaring the necessity for greater clarification (Regini 2000). This is also generally associated with the deregulation of the institutional settings that typified the Fordist age of capitalism, i.e. the minimization of all restrictions on individual behaviours and of the functions performed by the state and organized interests. As a result, various forms of non-standard employment relations (e.g. temporary and part-time work) have become increasingly prominent ways of organizing work. In particular, while numerous jobs have been created in the tertiary sector, these are often insecure and poorly paid. The decline in life-time jobs and the increase of flexible and nonstandard employment has a particularly destabilizing impact on employment systems. These jobs do not reflect the traditional standards of social reproduction, and therefore entail a weakening of the mechanisms of social integration, resulting in a increased risks of exclusion (Mingione 1997b).

\section{Data and method}

A two-stage Principal Component Analysis (PCA) was used to classify 16 European countries according to their labour regime model. In particular, this analysis focuses on Western European economies since these have been most often studied by the welfare regime literature. The aim of PCA is to identify a limited number of principal components that synthesize the greatest part of the variance of an original set of variables. This method has been applied in comparative analyses of the welfare state in order to explore the dimensionality underlying 
different welfare regimes, and to classify countries accordingly (Hicks and Kenworthy 2003; Shalev 2007; Wildeboer Schut et al. 2001). One of the assumptions of PCA is that of the independence or orthogonality of the principal components. However, it is often difficult to conceive truly independent dimensions, especially when considering socio-economic phenomena (Shalev 2007). In particular, the two dimensions used to define labour regimes - selectivity and regulation - are clearly not independent since everywhere women, youth and older people are more involved in non-standard jobs than other population groups (OECD 2006) ${ }^{3}$. The orthogonality constraint may in this case bias the underlying dimensions by inflating the contribution of variables that are highly collinear. Two-stage PCA avoids this problem by running separate analysis for each theoretically relevant dimension (Di Franco and Marradi 2013). In the first stage, the whole set of variables is analyzed in order to portray the semantic space of the indicator variables and to single out meaningful clusters of variables ${ }^{4}$. Subsequently, separate PCAs are performed on each subset to produce the final loadings and scores. During this stage, only the first component is extracted since it synthesizes the greatest part of the total variance and the greatest number of variables with high loadings. This procedure has also the advantage to avoid some of the inductive bias of PCA, which has been criticized for not sufficiently linking theory and empirical measurement (Shalev 2007).

This analysis uses data from the Eurostat Labour Force Survey 2007 for the EU 15 countries, Switzerland and Norway ${ }^{5}$, a period of relative stability in Europe before the onset of the financial crisis. Since the selection dimension measures the extent to which population groups are integrated in formal employment, age and gender specific employment ratios were used to measure this dimension. The employment rate of prime age men (25-54 years) was excluded because of the low degree of cross-national variation and its weak association with the other variables. This suggests that differences in male employment depend largely from other phenomena (e.g. business cycle, productive structure) than those primarily influencing the other demographic segments. The first component accounts for $74 \%$ of the total variance and all the variables show very high and positive loadings $(\geq 0.70)$ (table 1$)$. This component identifies a dimension that moves from a minimum to a maximum of selectivity.

[Table 1]

The regulation dimension is measured through an index of de-standardization that considers both the actual diffusion of forms of non-standard employment (self-employment, temporary, part-time work) and the strictness of formal regulations (EPL indicator) ${ }^{6}$. These indicators measure the extent to which employment relations differ from the Fordist ideal of lifelong, full-time, dependent employment. Given that this index measures countries' distance from the Fordist model of mobilization of labour, the shares of service and industrial employment were also included to illustrate the extent to which countries have shifted towards a post-Fordist 
economy, which is one of the factors commonly considered to foster the growth of non-standard work. The first component accounts for 53\% of the common variance and all the variables load significantly on it (table 2). This dimension describes different 'shapes' of employment relations: its positive and negative extremes point at the prevalence of different forms of non-standard work, while its centre is characterized by the prevalence of standard employment (Fordist regulation). More precisely, high values correspond to the prominence of self and temporary work and industrial activities, and low values to higher shares of employment in part-time and service jobs.

[Table 2]

Figure 1 plots each country's position based on their scores on the two dimensions. Four models of labour regimes are clearly distinguishable ${ }^{7}$ :

1) Flexible-exclusive countries (Italy, Greece, Portugal, Spain);

2) Standard-exclusive (Belgium, France);

3) Standard-inclusive (Germany, Ireland, Finland and Austria);

4) Flexible-inclusive (Denmark, Netherlands, Switzerland, Norway, Sweden, United Kingdom).

[Figure 1]

The following section illustrates in detail each labour regime model (table 3). Further descriptive variables concerning mainly the characteristics of care, pensions and education systems have also been used (table 4). These variables were not used in the construction of the indexes, but they serve to facilitate comparisons between clusters and illustrate the possible linkages and interdependencies between welfare and labour regimes. .

[Table 3 and 4]

\section{Flexible-exclusive: familialistic regimes: (Italy, Greece, Spain, Portugal)}

The combination of family-centred welfare states and family-biased production systems has resulted in the limited engagement of these countries populations in salaried employment. These labour markets are the most selective in Europe, especially towards youths and women. According to Paci (1973), this phenomena represents a typical by-product of that model of belated capitalism characterizing these countries. This model shows in fact a tendency to select the most productive portions of the labour force (prime-age men, averagely educated and living in urban settings), while systematically excluding and/or only marginally using other potential labour force groups. Yet, their exclusion is never complete as they normally end up finding their 
subsistence in marginal and smaller industries. Indeed, it was during the period of industrial development that the foundations of the strong division typical of Mediterranean economies between a primary (large corporations) and secondary (precarious jobs in marginal/undeclared activities) labour markets were laid.

Familialistic regimes are normally depicted as having very rigid labour markets in spite of having some of the highest shares of atypical employment in Europe. The limited presence of individuals and families fully dependent on salaried income for their living represents a distinctive feature of this model (Andreotti et al. 2001). Self-employment and irregular activities in small family businesses and underground activities are traditionally widespread forms of work in these countries, while temporary jobs and new forms of 'pseudo' self-employment have also risen considerably (EIRO, 2002). The industrial structure of these countries is characterized by the prevalence of small and medium-size family enterprises, family ownership and comparatively larger shares of family workers. These features are largely the legacy of their belated industrial development, and of the historical presence of authoritarian regimes and strong political parties with a Christian democratic ideology (Andreotti et al., 2001). Both were adverse to forms of extreme proletarianization that could have led to the growth of manufacturing working class largely represented by Communist parties. Their common adherence to an organicist view of the family as the basic and natural unit of social functioning also deeply influenced the ambivalent familialism' of social policies in these countries (Saraceno 2004). As stated by Trifiletti (1999), in the face of weak states and scarce supports, families have been allowed to gather as many 'breadcrumbs of revenue' as they could by bringing together odds and ends of income wherever they could find them. This combination of strict regulations, generous provisions and limited diffusion of standard employment has given rise to strongly dualistic labour markets.

\section{Standard-exclusive: one-generation regimes: (France, Belgium)}

This labour regime is based on a division of labour among generations with only one generation (25-55 years) working at a time. Age represents the main criteria used to discriminate among potential labour force groups in these countries, while women's employment has been traditionally high and full-time (Morgan 2006). The limited engagement of population groups in the labour market stems from the combination of delayed entry of youths in the labour market and early exit of elderly people from the working life. However, whereas youth employment has been in constant decrease from the beginning of the 80s, older people's employment has experienced a moderate growth in the last decade. This has resulted from the partial reversal of the labour shedding strategy adopted by many continental economies following the economic crises of the Seventies (Ebbinghaus 2006). From the beginning of the Nineties, pension systems have been reformed under the combined pressure of financial strains, demographic trends and pressures from the European Union. However, these reforms have produced a limited effect. A 
strong institutional resilience appears to characterize this field of policies as every time an early retirement scheme was closed, it was replaced by another one a few months later (Mandin 2003). Moreover, the availability of multiple early retirement paths - e.g. the use of unconditioned unemployment benefits as a form of 'bridging pension' until normal retirement age - has also contributed to limit the effect of reforms on older people's labour market engagement (Ebbinghaus 2006). Hence, the overall result of reforms has often been to shift costs from one public programme to another.

Persistently strict regulations and limited diffusion of non-standard jobs are distinctive features of this regime. Both the dynamic of the political system and the characteristics of the labour market have been relevant in shaping this outcome. Labour market rigidity has played a smaller role in public debates and policy reforms than in other European countries. In particular, France is the among the few European country to have tighten rules on permanent employment (EPL) since the mid-80s (Vlandas 2013). A characteristic feature of French political discourse consists in the general distrust of pure market forces and a strong statist tradition that unites both left and right wing parties. Accordingly, governments have not generally acted to promote the use of atypical contracts and the few initiatives taken (e.g. by the right-wing government in 1986 to relax regulations of dismissal and the use of atypical contract) had soon to be withdrawn or watered down by subsequent governments. Large social mobilizations and public opinion hostility also played an important role in limiting the governments' possibility to relax labour protections in these countries (Levy 2005). Accordingly, labour market flexibilization has occurred mainly by 'stealth' (Barbier and Fargion 2004) and has always been limited by governments' necessity to 'come to terms with the streets' (Eichhorst 2007).

Finally, the considerable role played by the state as 'employer of last resort' explains to a large extent the dynamics of service expansion in these countries, which have some of the largest shares of service employment in Europe. In the face of increasing job shortage and according to a long -but apparently fading- tradition of 'dirigisme' (Schmidt 2003), the public sector has acted as a buffer to prevent what might have otherwise been a massive rise of unemployment. Accordingly, we find the highest share of civil servants within this regime model (13.6\%), while the creation of subsidized jobs (contract aides) has traditionally represented another privileged instrument used to tackle the unemployment of problem groups in the labour market - in particular, youths and low-skilled (Vail 2008). This has in the end contributed to an increase in 'government sponsored' labour market dualization - albeit more limited than in other continental economies - through the creation of a second tier of low skilled state-subsidized jobs (Eichhorst and Marx 2010; Palier and Thelen 2010)

\section{Standard-inclusive: Fordist regimes (Germany, Austria, Ireland, Finland)}

At first glance this group of countries strikes as a strangely assorted mix made up of different welfare regimes, two high growth economies in the period 1991-2007 (Austria and Ireland) and two countries that experienced severe economic downturns following some events 
at the beginning of the 90s (the German reunification and the Finnish great depression). Their belonging to the same model appears driven by their sharing a number of common features: 1) similar sectoral employment structures with considerable shares of industrial employment in large enterprises; 2) the prevalence of standard full-time waged employment with high levels of stability; 3) a growing engagement of population groups in paid employment, in particular of women and older people. Nevertheless, different starting points and evolutionary dynamics seem to characterize Germany and Austria on one side, and Ireland and Finland on the other. The first two countries represent clear cases of a distinctive model that has received much attention in scholarly literature (Albert 1991; Hall and Soskice 2001; Katzenstein 1985; Lash and Urry 1987; Shonfield 1965), while Ireland and Finland are notorious labour market outliers insofar that a lively debate has often spurred around the nature of their supposed exceptionalism (Cousins 1997; Elvander 2002).

This group of countries has experienced the most rapid and radical labour market changes. This labour regime is thus better understood as an ideal typical location with countries transitioning in different directions. The most relevant changes in Austria and Germany have concerned a significant increase of non-standard employment (e.g. part-time work, mini-jobs, agency work) according to a strategy of deregulation at the margins (cf. Shire and Tünte in this book). As a result, these countries' labour markets, once associated with 'few, but good jobs', are today experiencing a growing dualization of employment conditions. Finland and Ireland in turn were up to the onset of the 2007 recession essentially shifting along the selection dimension. The major change in these countries' labour regime has concerned the increased participation of different groups of population in paid work (mostly with regard to older people in Finland and women in Ireland $)^{8}$. Nonetheless, the labour regime of these two countries continues to configure a distinct model.

\section{Flexible inclusive: half-time work-centred regimes (Denmark, Netherlands, Norway, Sweden, Switzerland, United Kingdom)}

The countries belonging to this labour regime are work-centred societies emphasizing the right/obligation of its members to work (Leibfried 1992). Marginal labour force groups enjoy higher employment rates than in all the other models ${ }^{9}$; yet, more than elsewhere, women, older people and youth are in part-time jobs. Therefore, the radical nature of the commodification labour -the degree according to which people engage in work in exchange for a salary- is counterbalanced by the large diffusion of reduced working hours. Part-time work is also more voluntary than in the other models: only $12.8 \%$ of part-timers declare that they would like to work more hours, compared to a European average of $21.6 \%$, and as much as $38.2 \%$ in familialistic countries. The employment systems of these countries also shows very high shares of service employment, whether in the public sector as in the Nordic countries or in personal 
services and other private sector activities as in the United Kingdom, and to some extent in the Netherlands.

Consistent with this emphasis on labour mobilization, individuals' integration in employment is explicitly targeted through measures aimed at activating labour supply. Indeed, it is within this group that we find both the country that first developed active labour market policies as far back as the 1940s (Sweden), and the forerunners of the flexicurity (Denmark, Netherlands) and workfare (United Kingdom) approaches. Nevertheless, there are considerable differences between these two ideal types of activation, concerning in particular the role of the labour market, the legitimacy of individual claims on society and the responsibilities of the state. According to Dingley (2007) differences can be subsumed under three dimensions: 1)the stringency of labour market participation criteria; 2) the conditionality of rights on individuals' obligations; 3) the promotion of employability and social equity and the provision of services. Simplifying, we can state that while the liberal workfare model emphasises the first two aspects, the universalistic flexicurity approach stresses the last one. Recently, however, northern European countries have also increased individuals' obligations to find and accept a job due to pressures to contain social expenditures(van Oorschot and Abrahamson 2003).

The fact that we find within this regime model both more residual (United Kingdom) and universalistic welfare states (Scandinavian countries) may appear inconsistent. However, the belonging of these countries to the same model is determined by their having found the same solution for their labour markets (vigorous employment promotion) in spite of differences in the ways their welfare states are organized. In this view, Hicks and Kenworthy (2003) show that, including family and work policies among the dimensions used to classify welfare regimes, liberal and social democratic welfare states lie at the opposite poles of the same dimension (labelled 'progressive liberalism'), implying similar effects on 'jobs' (employment, share of female of the labour force) but different effects on 'incomes' (poverty reduction, female share of earnings). These two models of welfare regimes are also more similar than one would first say. On one hand, social-democratic welfare states have been supportive of decommodification measures insofar they did not reduce aggregate levels of employment. These countries actually provide the most convincing evidence against the widespread idea that generous social provisions necessarily produce high unemployment levels. Huo et al. (2008) demonstrate that the apparent paradox of Nordic countries - having at the same time generous decommodifying social protection and highly commodified labour markets - disappears once we take into account the differential employment-effect of social policies. In this view, social-democratic states are keen on employment-friendly measures and generous short-term unemployment benefits insofar as they do not reduce aggregate employment levels and leave few options for people to live outside the labour market (e.g. disability, health conditions) ${ }^{10}$. On the other hand, the social-democratic and liberal welfare states also share some similar features -generally subsumed under the Beveridgean social policy category- with regard to sources of financing (taxation) and demarcation of 
entitlements (citizenships), but differ with regard to the criteria giving access to benefits (right and need, respectively) and their level (higher or lower) of generosity (Abrahamson 2006). As otherwise stated by Huber and Stephens, "the essence of the social democratic welfare state is not decommodification, but rather high qualification and participation in the labour market", while the main source of differences from the liberal welfare state lies the ways individuals are treated when involuntarily separated from the labour market (2001:184).

\section{Conclusions}

It is often difficult to set a clear separation between labour regimes and other aspects of national political economies such as social protection, production and industrial relation systems since the boundaries between these institutional complexes are often blurred both conceptually and empirically (Ebbinghaus and Manow 2001). Nevertheless, the inclusion of labour markets and worlds of employment within comparative political economy literature has shown a strong tendency to be entirely subsumed within typologies of welfare states, in spite of the multiple and complex interactions between these two institutional spheres (Wincott 2001). The main argument of this chapter is that we cannot easily assume a one-to-one relationship between welfare and labour regimes and that existing classification of welfare regimes may at best provide a partial understanding of the functioning of labour markets because they neglect differences in the ways in which the commodification of labour has historically taken place across countries. Accordingly, this analysis takes a different starting point by looking at the ways in which labour is mobilized in different political economies. This definition of a labour regime yields four distinct types- flexible-exclusive, standard-exclusive, standard-inclusive and flexible-inclusive. Qualitative differences between these models concern their degree of selectivity towards different population groups, and the relative importance of various forms of non-standard employment relations.

These four labour regime models only partly coincide with prevalent welfare state typologies. First, conservative welfare regimes do not form a coherent cluster. Conversely, both the liberal and social-democratic welfare states belong to the same labour regime - half-time work-centred. Therefore, different welfare forms appear to go hand in hand with similar labour market outcomes (e.g. radical but part-time proletarianization). Indeed, welfare states contribute to shaping different labour regimes, as shown by the fact that different degrees and kinds of selectivity are influenced by the characteristics of education and training systems, the availability of pensions, disability, family and other income support programmes. Nevertheless, there is no clear evidence on the actual direction of this causal link (from welfare to labour regimes or from labour welfare regimes) and their relationship is better conceptualized as one of reciprocal 
causation. Thus, while some dimension of their variation might clearly fall in both domains, other factors and institutions must also have been influential in shaping these different employment models, such as demographic variables, immigration/emigration dynamics, productive systems, family models, or country size. This suggests that "the same welfare state regime is compatible with different -but not any- labour market institutions and policies" (Huber \& Stephens, 2001:90). 


\section{REFERENCES}

Abrahamson, Peter. 1999. “The Welfare Modelling Business.” Social Policy \& Administration 33(4):394-415.

Abrahamson, Peter. 2006. "Welfare Reform: Renewal or Deviation?” Pp. 356-74 in National identity and the varieties of capitalism: The Danish experience. Montreal: McGill University Press.

Albert, Michel. 1991. Capitalisme Contre Capitalisme. Paris: Seuil.

Amable, Bruno, Lilas Demmou, and Donatella Gatti. 2011. "The Effect of Employment Protection and Product Market Regulation on Labour Market Performance: Substitution or Complementarity?" Applied Economics 43(4):449-64.

Andreotti, Alberta et al. 2001. "Does a Southern European Model Exist?” Journal of European Area Studies 9(1):43-62.

Arrighi, Giovanni, Kenneth Barr, and Shuji Hisaeda. 1999. "The Transformation of Business Enterprise." Pp. 97-150 in Giovanni Arrighi and Beverly J. Silver, Chaos and Governance in the Modern World System. Minneapolis and Lodon: University of Minessota Press.

Baccaro, Lucio, and Diego Rei. 2007. "Institutional Determinants of Unemployment in OECD Countries: Does the Deregulatory View Hold Water?" International Organization 61(03):527-69.

Baranowska, Anna, and Michael Gebel. 2010. "The Determinants of Youth Temporary Employment in the Enlarged Europe.” European Societies 12(3):367-90.

Barbieri, Paolo. 2009. "Flexible Employment and Inequality in Europe.” European Sociological Review 25(6):621-28.

Barbier, J. C. 1998. “Les Politiques Publiques de L'emploi En Perspective: Pour Un Cadre de Comparaison Des Politiques Nationales de L'emploi." Cahiers du Centre d'études de l'emploi (37):383-410.

Barbier, Jean-Claude, and Valeria Fargion. 2004. "Continental Inconsistencies on the Path to Activation: Consequences for Social Citizenship in Italy and France." European Societies 6(4):437-60.

Bassanini, Andrea, and Romain Duval. 2006. "The Determinants of Unemployment across OECD Countries: Reassessing the Role of Policies and Institutions." OECD Economic Studies n. 42.

Baxandall, Phineas. 2002. "Explaining Differences in the Political Meaning of Unemployment across Time and Space.” The Journal of Socio-Economics 31(5):469502. 
Belot, Michele, and Jan C. Van Ours. 2004. "Does the Recent Success of Some OECD Countries in Lowering Their Unemployment Rates Lie in the Clever Design of Their Labor Market Reforms?" Oxford Economic Papers 56(4):621-42.

Bertola, Giuseppe, Francine D. Blau, and Lawrence M. Kahn. 2007. "Labor Market Institutions and Demographic Employment Patterns." Journal of Population Economics 20(4):833-67.

Bonoli, Giuliano. 1997. "Classifying Welfare States: A Two-Dimension Approach.” Journal of social policy 26(3):351-72.

Bosch, Gerhard. 2004. "Towards a New Standard Employment Relationship in Western Europe." British journal of industrial relations 42(4):617-36.

Bosch, G., S. Lehndorff, and J. Rubery. 2009. European Employment Models in Flux: A Comparison of Institutional Change in Nine European Countries. Palgrave Macmillan. Retrieved October 25, 2012

Boyer, Robert. 1986. La Théorie de La Régulation: Une Analyse Critique. Paris: La Découverte.

Calmfors, Lars, and John Driffill. 1988. "Bargaining Structure, Corporatism and Macroeconomic Performance.” Economic Policy 3(6):13-61.

Castles, Francis G., and Deborah Mitchell. 1993. "Worlds of Welfare and Families of Nations." Families of nations: Patterns of public policy in western democracies 93(94,112).

Clasen, Jochen, and Daniel Clegg, eds. 2011. Regulating the Risk of Unemployment: National Adaptations to Post-Industrial Labour Markets in Europe. Oxford: Oxford University Press.

Cousins, Mel. 1997. "Ireland's Place in the Worlds of Welfare Capitalism." Journal of European Social Policy 7(3):223-35.

Crompton, Rosemary. 2006. Employment and the Family: The Reconfiguration of Work and Family Life in Contemporary Societies. Cambridge: Cambridge University Press.

Deeg, R., and G. Jackson. 2007. "Towards a More Dynamic Theory of Capitalist Variety." Socio-Economic Review 5(1):149-79.

Dingeldey, Irene. 2007. "Between Workfare and enablement-The Different Paths to Transformation of the Welfare State: A Comparative Analysis of Activating Labour Market Policies." European Journal of political research 46(6):823-51.

Ebbinghaus, Bernhard. 2006. Reforming Early Retirement in Europe, Japan and the USA. Oxford: Oxford University Press.

Ebbinghaus, Bernhard, and Philip Manow, eds. 2001. Comparing Welfare Capitalism: Social Policy and Political Economy in Europe, Japan and the US. London and New York: Routledge. 
Eichhorst, Werner. 2007. "The Gradual Transformation of Continental European Labor Markets: France and Germany Compared". IZA Discussion Papers 2675, Bonn: Forschungsinstitut zur Zukunft der Arbeit.

Eichhorst, Werner, and Paul Marx. 2010. Whatever Works: Dualisation and the Service Economy in Bismarckian Welfare States. IZA Discussion Papers 5035, Bonn: Forschungsinstitut zur Zukunft der Arbeit.

EIRO, 2002, “Economically dependent workers', employment law and industrial relations", Dublin: European Foundation for the Improvement of Living and Working Conditions, http://www.eiro.eurofound.eu.int/2002/05/study/TN0205101S.html

Elvander, Nils. 2002. "The Labour Market Regimes in the Nordic Countries: A Comparative Analysis." Scandinavian Political Studies 25(2):117-37.

Erhel, Christine, and Hélène Zajdela. 2004. "The Dynamics of Social and Labour Market Policies in France and the United Kingdom: Between Path Dependence and Convergence." Journal of European Social Policy 14(2):125-42.

Esping-Andersen, Gosta. 1990. The Three Worlds of Welfare Capitalism. Cambridge: Polity Press.

Esping-Andersen, Gosta. 1999. Social Foundations of Postindustrial Economies. Oxford University Press.

Ferrera, Maurizio. 1993. Modelli Di Solidarietà. Politica E Riforme Sociali Nelle Democrazie. Bologna: Mulino.

Di Franco, Giovanni, and Alberto Marradi. 2013. Factor Analysis and Principal Component Analysis. Milano: Franco Angeli.

Gallie, Duncan. 2007a. Employment Regimes and the Quality of Work. Oxford University Press Oxford. Retrieved April 21, 2014 (http://www.nyt-omarbejdsliv.dk/images/pdf/2008/nr4/tfa4_2008_121-123.pdf).

Gallie, Duncan. 2007b. "Welfare Regimes, Employment Systems and Job Preference Orientations." European Sociological Review 23(3):279-93.

Gramsci, Antonio. 1949. Quaderno 22 Americanismo E Fordismo. Torino: Einaudi.

Hall, Peter, and David Soskice. 2001. Varieties of Capitalism: The Institutional Basis of Competitive Advantage. Oxford: Oxford University Press.

Hicks, Alexander, and Lane Kenworthy. 2003. "Varieties of Welfare Capitalism." Socioeconomic review 1(1):27-61.

Huber, E., and J. D. Stephens. 2001. Development and Crisis of the Welfare State: Parties and Policies in Global Markets. Chicago: University of Chicago Press.

Huo, J., M. Nelson, and J. D. Stephens. 2008. "Decommodification and Activation in Social Democratic Policy: Resolving the Paradox.” Journal of European Social Policy 18(1):5-20. 
Iversen, Torben, and Anne Wren. 1998. "Equality, Employment and Budgetary Restraint, the Trilemma of the Service Economy." World Politics 50(4):507-46.

Jensen, Carsten. 2008. "Worlds of Welfare Services and Transfers.” Journal of European Social Policy 18(2):151-62.

Kahn, Lawrence M. 2007. "The Impact of Employment Protection Mandates on Demographic Temporary Employment Patterns: International Microeconomic Evidence*.” The Economic Journal 117(521):F333-56.

Katzenstein, Peter J. 1985. Small States in World Markets: Industrial Policy in Europe. Ithaca: Cornell University Press.

Knijn, T., and I. Ostner. 2002. “6. Commodification and de-Commodification.”. Pp. 141-169 in Contested concepts in gender and social politics, edited by Barbara Hobson, Jane Lewis, and Birte Siim. Cheltenham, UK: Edward Elgar.

Korpi, W., and J. Palme. 1998. "The Paradox of Redistribution and Strategies of Equality: Welfare State Institutions, Inequality, and Poverty in the Western Countries." American sociological review 661-87.

Lash, Scott, and John Urry. 1987. The End of Organized Capitalism. Madison: University of Wisconsin Press.

Layard, Richard, P. Richard G. Layard, Stephen J. Nickell, and Richard Jackman. 1991. Unemployment: Macroeconomic Performance and the Labour Market. Oxford: Oxford University Press.

Leibfried, S. 1992. "Towards a European Welfare State? On Integrating Poverty Regimes into the European Community." Pp. 245-80 in Social Policy in a Changing Europe. Frankfurt am Main: Campus Verlag.

Levy, Jonah. 2005. "Redeploying the State: Liberalization and Social Policy in France." Pp. 103-26 in Beyond Continuity: Institutional Change in Advanced Political Economies. Oxford: Oxford University Press.

Lewis, Jane. 1992. "Gender and the Development of Welfare Regimes." Journal of European social policy 2(3):159-73.

Littlewood, Paul, Ignace Glorieux, and Ingrid Jönsson. 2004. The Future of Work in Europe. Aldershot: Ashgate.

Lynch, Julia. 2006. Age in the Welfare State: The Origins of Social Spending on Pensioners, Workers, and Children. Cambridge: Cambridge University Press.

Mandin, Christelle. 2003. "From Early Retirement to Active Ageing: The Evolution of Social Policies for Older Workers in France and Germany." paper presented at the 4th International Social Security Association, 5-7 May 2003 Antwerp.

Mingione, Enzo. 1997a. Sociologia Della Vita Economica. Milano: Carocci. 
Mingione, Enzo. 1997b. "The Current Crisis of Intensive Work Regimes and the Question of Social Exclusion in Industrialized Countries". WZB Discussion Paper No. FS I 97105. Berlin: Wissenschaftszentrum Berlin für Sozialforschung.

Morgan, Kimberly J. 2006. Working Mothers and the Welfare State: Religion and the Politics of Work-Family Policies in Western Europe and the United States. Stanford, CA: Stanford University Press.

Muffels, Ruud, Ton Wilthagen, and Nick van den Heuvel. 2002. "Labour Market Transitions and Employment Regimes: Evidence on the Flexibility-Security Nexus in Transitional Labour Markets.” Retrieved April 21, 2014 (http://mpra.ub.uni-muenchen.de/13301/).

O’Connor, J. S., Ann Shola Orloff, and S. Shaver. 1999. States, Markets, Families: Gender, Liberalism, and Social Policy in Australia, Canada, Great Britain, and the United States. Cambridge: Cambridge University Press.

OECD. 2006. "Chapter 4. Policies Targeted at Specific Workforce Groups or Labour Market Segments.” Pp. 127-56 in Employment Outlook. Paris: OECD.

Offe, Claus. 1985. Disorganized Capitalism: Contemporary Transformations of Work and Politics. Cambridge, MA: MIT University Press.

Van Oorschot, Wim, and Peter Abrahamson. 2003. "The Dutch and Danish Miracles Revisited: A Critical Discussion of Activation Policies in Two Small Welfare States." Social Policy \& Administration 37(3):288-304.

Orloff, A. S. 1993. "Gender and the Social Rights of Citizenship: The Comparative Analysis of Gender Relations and Welfare States." American sociological review 58(3):303-28.

Paci, Massimo. 1973. "Migrazioni Interne E Mercato Capitalistico Del Lavoro.” in Sviluppo economico in Italia e forza-lavoro, vol. 27. Bologna: Il Mulino.

Palier, Bruno, and Kathleen Thelen. 2010. "Institutionalizing Dualism: Complementarities and Change in France and Germany." Politics \& Society 38(1):119-48.

Pfau-Effinger, Birgit, Lluís Flaquer, and Per H. Jensen. 2009. Formal and Informal Work: The Hidden Work Regime in Europe. Taylor \& Francis.

Pioch, Roswitha. 2004. "Transnational Labour Markets, Citizenship and Welfare State Reform." Pp. 49-64 in The Future of Work. Aldershot: Ashgate.

Polanyi, Karl. 1944. The Great Transformation: The Political and Economic Origins of Our Time. Boston: Beacon Press.

Regini, Marino. 2000. Modelli Di Capitalismo. Le Risposte Europee Alla Sfida Della Globalizzazione. Laterza. Bari.

Rubery, Jill, and Damian Grimshaw. 2003. The Organization of Employment: An International Perspective. London: Palgrave.

Sainsbury, Diane. 1994. Gendering Welfare States. London: Sage. 
Saraceno, C. 2004. Le Dinamiche Assistenziali in Europa. Sistemi Nazionali E Locali Di Contrasto Alla Povertà. Bologna: Il Mulino.

Saraceno, Chiara. 1987. "La Famiglia: I Paradossi Della Costruzione Del Privato." in La vita privata. Il Novecento. Bari: Laterza.

Schmid, Günther, and Bernard Gazier. 2002. The Dynamics of Full Employment: Social Integration through Transitional Labour Markets. Edward Elgar Publishing.

Schmidt, Vivien. 2003. "French Capitalism Transformed, yet Still a Third Variety of Capitalism." Economy and Society 32(4):526-54.

Shalev, Michael. 2007. "Limits and Alternatives to Multiple Regression in Comparative Research." Comparative Social Research 24(3):261-308.

Shonfield, Andrew. 1965. Modern Capitalism. The Changing Balance of Public and Private Power. Oxford: Oxford University Press.

Spilerman, Seymour. 2009. "How Globalization Has Impacted Labour: A Review Essay." European sociological review 25(1):73-86.

Stephens, John D. 1994. "Welfare State and Employment Regimes." Acta Sociologica 37(2):207-11.

Supiot, Alain. 2001. Beyond Employment: Changes in Work and the Future of Labour Law in Europe. Oxford: Oxford University Press.

Titmuss, Richard M. 1958. Essays on'The Welfare State'. London: Allen \& Unwin.

Trifiletti, Rossana. 1999. "Southern European Welfare Regimes and the Worsening Position of Women." Journal of European Social Policy 9(1):49.

Vail, Mark I. 2008. “From 'welfare without Work’to ‘buttressed Liberalization': The Shifting Dynamics of Labor Market Adjustment in France and Germany." European journal of political research 47(3):334-58.

Vlandas, Tim. 2013. "The Politics of Temporary Work Deregulation in Europe: Solving the French Puzzle." Politics \& Society 41(3): 425-460.

Vos, Allison E. 2009. "Falling Fertility Rates: New Challenges to the European Welfare State." Socio-Economic Review 7(3):485-503.

Wildeboer Schut, J. M., J. C. Vrooman, and P. T. De Beer. 2001. On Worlds of Welfare. The Hague: SCPO.

Wincott, Daniel. 2001. "Reassessing the Social Foundations of Welfare (state) Regimes." New Political Economy 6(3):409-25. 


\section{Tables and Figures}

Table 1: Principal component analysis of selection dimension (2007)

\section{Variables}

\section{Component \\ Loadings}

\section{Component \\ score \\ coefficients}

Male employment ratio 15-19 years

Male employment ratio 20-24 years

0.89

0.17

0.95

0.18

0.73

0.14

0.95

0.18

0.97

0.18

0.81

0.15

0.76

0.14

Note: Estimates relative to the first component calculated by principle component method with varimax rotation; the component has an eigenvalue above 5 .

Table 2: Principal component analysis of standardization dimension

\begin{tabular}{lrr}
\hline Variables & $\begin{array}{c}\text { Component } \\
\text { Loadings }\end{array}$ & $\begin{array}{c}\text { Component } \\
\text { score } \\
\text { coefficients }\end{array}$ \\
\hline Employment in services (\% total employment) & -0.92 & -0.29 \\
Part-time/full time ratio & -0.72 & -0.23 \\
Employment in industry (\% total employment) & 0.82 & 0.26 \\
Employment protection legislation (EPL) & 0.64 & 0.20 \\
Self-employment/dependent employment & 0.63 & 0.20 \\
Temporary/permanent employment & 0.57 & 0.18 \\
\hline
\end{tabular}

Note: Estimates relative to the first component calculated by principle component method with varimax rotation; the component has an eigenvalue of 3.2. 
Table 3: Labour regimes' characteristics, 2007

\begin{tabular}{|c|c|c|}
\hline Labour regime & Selection & Regulation and main reform pattern \\
\hline \multirow[t]{5}{*}{ Familialistic } & High & Low standardized and high regulated \\
\hline & $(-)$ women & $(+)$ self \\
\hline & $(-)$ youth & (+) temporary \\
\hline & & $(-)$ part-time \\
\hline & & (+) agriculture and industrial employment \\
\hline \multirow[t]{5}{*}{ One-generation } & High & High standardized and high regulated \\
\hline & $(-)$ older people & $(-)$ self-employment \\
\hline & $(-)$ youth & $(-)$ temporary \\
\hline & & $(-)$ part-time \\
\hline & & (+) service employment (public) \\
\hline \multirow[t]{5}{*}{ Fordist } & Average-low & High standardized and high regulated \\
\hline & $(+)$ youth & () self-employment \\
\hline & $(+)$ women & $(-)$ temporary \\
\hline & $(-)$ older workers & (+) (marginal) part-time \\
\hline & & (+) industrial employment (large corporations) \\
\hline \multirow[t]{5}{*}{ Half-time } & Low & Low standardized and low regulated \\
\hline & $(+)$ women & $(-)$ self-employment \\
\hline & $(+)$ youth & $(-)$ temporary \\
\hline & $(+)$ older workers & (+) part-time \\
\hline & & (+) service employment \\
\hline
\end{tabular}


Table 4: Descriptive variables per labour regime model, 2007

\begin{tabular}{|c|c|c|c|c|}
\hline \multirow[b]{2}{*}{ Variables } & \multicolumn{4}{|c|}{ Labour regime } \\
\hline & Half-time & Fordist & $\begin{array}{c}\text { One- } \\
\text { generation }\end{array}$ & Familialistic \\
\hline $\begin{array}{l}\text { Non-standard work (\% of total } \\
\text { employment) }\end{array}$ & 51.9 & 41.9 & 41.4 & 48.2 \\
\hline $\begin{array}{l}\text { Family workers (\% of total } \\
\text { employment })^{1}\end{array}$ & 0.6 & 0.9 & 0.9 & 2.5 \\
\hline $\begin{array}{l}\text { Employment in public administration } \\
\text { (\% of total service employment })^{1}\end{array}$ & 8.1 & 9.0 & 13.6 & 10.7 \\
\hline $\begin{array}{l}\text { Involuntary part-time work (\% of total } \\
\text { employment) }{ }^{1}\end{array}$ & 13.0 & 19.0 & 24.2 & 39.0 \\
\hline Total fertility rate ${ }^{2}$ & 1.77 & 1.65 & 1.98 & 1.37 \\
\hline $\begin{array}{l}\text { Mothers of children }<14 \text { years working } \\
\text { full-time using relatives/neighbours/ } \\
\text { friends as main type of childcare }\end{array}$ & 9.4 & 12.9 & 24.5 & 33.5 \\
\hline $\begin{array}{l}\text { Expenditure on family policies ( } \% \text { of } \\
\text { GDP) }\end{array}$ & 2.3 & 2.9 & 2.3 & 1.3 \\
\hline Early school leavers (18-24 years) ${ }^{5}$ & 13.2 & 10.8 & 12.5 & 25.2 \\
\hline Participation rate of youth in education ${ }^{5}$ & 61.8 & 61.9 & 64.4 & 57.3 \\
\hline $\begin{array}{l}\text { Workforce (15-64 years) with low } \\
\text { educational attainment }{ }^{1}\end{array}$ & 41.9 & 32.4 & 20.6 & 46.4 \\
\hline $\begin{array}{l}\text { Workforce (15-64 years) with tertiary } \\
\text { education }{ }^{1}\end{array}$ & 31.6 & 28.7 & 34.1 & 22.3 \\
\hline $\begin{array}{l}\text { Male average actual retirement age } \\
(2002-2007)^{6}\end{array}$ & 63.4 & 62.2 & 59.1 & 62.5 \\
\hline $\begin{array}{l}\text { Female average retirement age (2002- } \\
2007)^{6}\end{array}$ & 62.3 & 61.3 & 58.9 & 62.6 \\
\hline $\begin{array}{l}\text { Expenditure on early retirement for } \\
\text { labour market reason }(\% \text { GDP })^{4}\end{array}$ & 0.0 & 0.13 & 0.25 & 0.03 \\
\hline $\begin{array}{l}\text { Expenditure on disability pensions (\% } \\
\text { GDP) }{ }^{4}\end{array}$ & 2.0 & 1.2 & 1.1 & 1.2 \\
\hline
\end{tabular}

Sources: ${ }^{1}$ EULFS, 2007 , non-standard work refers to temporary, part-time,and self-employment. ${ }^{2}$ ${ }^{2}$ Eurostat demographic indicators; ${ }^{3}$ EULFS $a d$ hoc module 2005; ${ }^{4}$ ESSPROSS database, 2006; ${ }^{5}$ EUROSTAT Education and training statistics, $2007 ;{ }^{6}$ OECD pensions at a glance, average 2002-2007. 
Figure 1: Labour regime clusters, 2007*

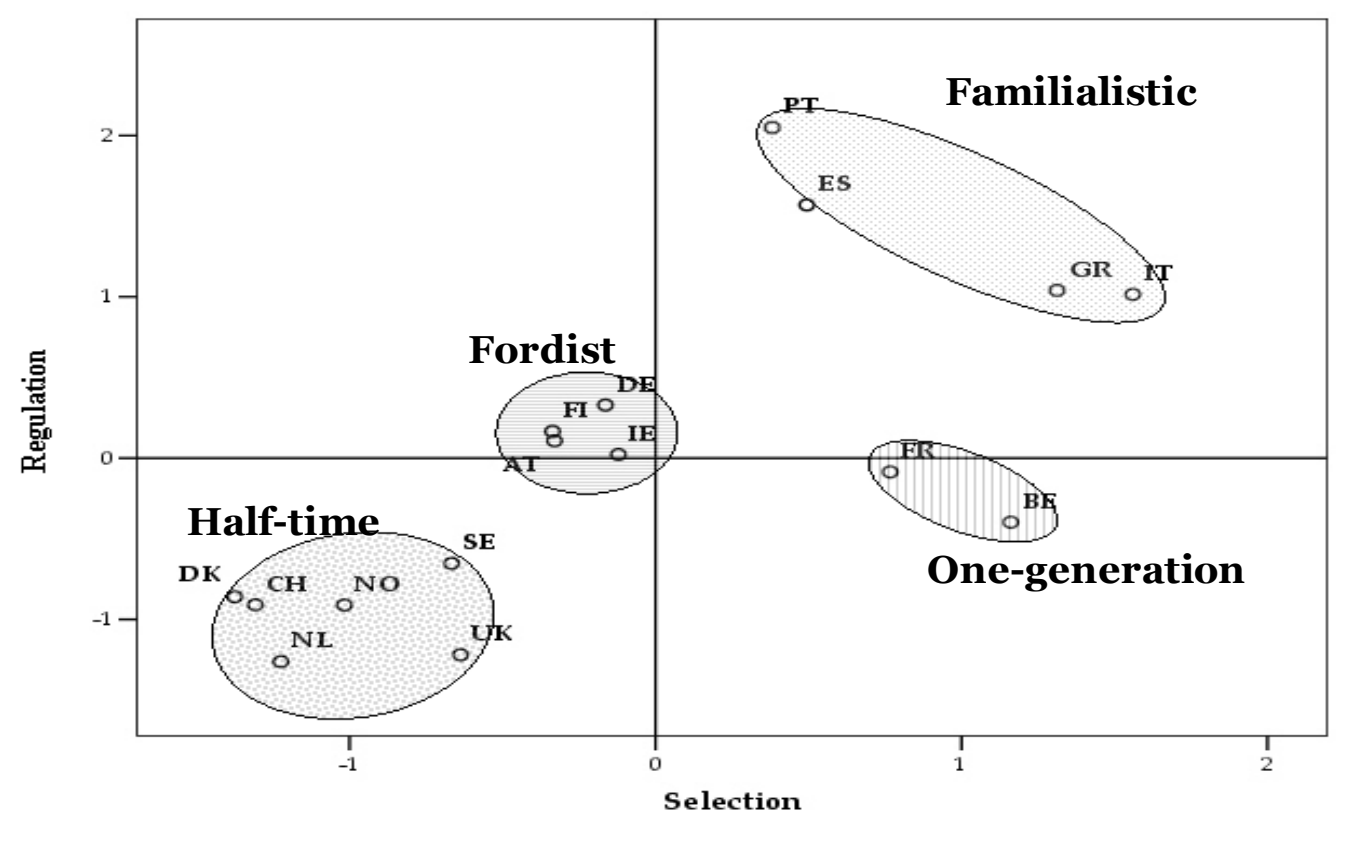

*The sign of the selectivity scores has been reversed to facilitate their interpretation (negative scores=low selectivity, high scores $=$ strong selectivity)

\section{Notes}

${ }^{1}$ Data refers to the average employment rate 15-64 years in the EU15, Norway and Switzerland (EULFS data, 2007).

2 Other commonly used criteria that are not analyzed in this chapter are ethnicity and physical conditions/disability (Offe 1985).

3 There is a positive correlation of 0.69 between selection and de-standardization. However, repeating the analysis for 1991 leads to a value of only 0.51 , indicating that the relation is contingent and becoming stronger with time.

4 The first two components of a PCA analysis with varimax rotation on all thirteen indicators account for $69 \%$ of the total variance. The selectivity indicators load strongly on the first component $(>0.80)$. The second component is defined chiefly by temporary employment $(-.86)$, industrial employment (-.71); EPL (-.70) and service employment (0.73). As expected, part-time work loads positively on both components (.64 and 0.40$)$.

${ }^{5}$ Luxembourg was excluded from the analysis because of the peculiarities of its economy (GDP per capita and financial activities considerably above EU average) and the small dimension of its resident population.

${ }^{6}$ Data referes to the OECD indicator of EPL version 1, which contains information on temporary and permanent contracts, but leaves out regulations on collective dismissals.

7 This result was confirmed by a hierarchical cluster analysis on the component loadings using Ward's method of agglomeration.

8 The recession in 2007-2008 will have considerable impact on the Irish labour market, pointing at an increase importance of involuntary part-time work and other forms of underemployment. See, for instance, Murphy and Loftus in this book. 
9 Selectivity in this labour regime could be rather directed towards migrant workforce. In 2001, the difference between the unemployment rate of male foreign and natives workers in Sweden was equal to $10.6 \%$ and in all the countries belonging to this regime model foreigners are between 2-3 times more unemployed than national (Pioch 2004). This ratio is more or less equal to 1 in familialistic regimes.

${ }^{10}$ Disability benefits represent one of the traditional few exit routes from the labour market in this labour regime, with expenditure levels ( $2 \%$ of GDP) that are on average double those of other labour regimes. 